This item was submitted to Loughborough's Research Repository by the author.

Items in Figshare are protected by copyright, with all rights reserved, unless otherwise indicated.

\title{
Meanings of place and aspects of the Self: an interdisciplinary and empirical account
}

PLEASE CITE THE PUBLISHED VERSION

http://dx.doi.org/10.1007/s10708-009-9290-9

PUBLISHER

(C) Springer

VERSION

AM (Accepted Manuscript)

\section{PUBLISHER STATEMENT}

This work is made available according to the conditions of the Creative Commons Attribution-NonCommercialNoDerivatives 4.0 International (CC BY-NC-ND 4.0) licence. Full details of this licence are available at: https://creativecommons.org/licenses/by-nc-nd/4.0/

\section{LICENCE}

CC BY-NC-ND 4.0

\section{REPOSITORY RECORD}

Antonsich, Marco. 2019. "Meanings of Place and Aspects of the Self: An Interdisciplinary and Empirical Account”. figshare. https://hdl.handle.net/2134/16114. 


\title{
Meanings of place and aspects of the Self: \\ An interdisciplinary and empirical account
}

\begin{abstract}
Although geographers have largely investigated the notion of place, the relationship between place and Self does not seem to have received a similar attention, both theoretically and empirically. After the initial interest expressed by humanistic geographers, social constructivism and cultural materialism (two dominant paradigms in use since at least the 1980s) have somewhat moved the interest towards a sort of social(izing) discourse, which has pushed the individual dimension to the margin. Accordingly, this dimension has been treated as a mere product of social discourses, as purely embodying and (re)enacting certain social categories (gender, sex, race, etc.) or, again, it has been discredited as psychologically 'mentalistic' and geographically 'trivial'. In the present article, I aim to rescue this personal, intimate dimension and show how, beyond an all-encompassing social(izing) logic, it remains at work in the ways people relate to place. Theoretically, the study builds on the early contributions of humanistic geographic, complemented with more recent works in environmental and social psychology. Empirically, it is grounded in narratives of place collected during interviews and focus groups administered in four regional case studies in Western Europe. The article advances and illustrates, with empirical materials, a simple theoretical framework, which aims to contribute to the understanding of how meanings of place implicate and are implicated in the construction of the Self.
\end{abstract}


Key words: place, identity, Self, humanistic geography, environmental psychology 


\section{Introduction}

In the 1970s, the study of the relationship between place and the Self attracted the interests of various geographers. Drawing on a phenomenological paradigm, the works of Tuan (1974a; 1974b), Relph (1976), and Buttimer and Seamon (1980), among others, contributed substantially to the exploration of the ways in which the subject constructs her/him-Self by intentionally attributing meanings to places (Dixon and Durrheim 2004, p. 457). Notions of sense of place, rootedness, insideness, or topophilia - as well as its antinomic dimension, topophobia (Tuan, 1974b, 1980a; Muñoz González, 2005) - have since become of common usage in geography, as well as in other social sciences. It is noteworthy, for instance, that in environmental psychology the names of Tuan and Relph are still today largely cited. Yet, it is also noteworthy that, apart from very occasional citations of Massey, Pile, and Agnew (Gustafson 2001a; Manzo 2003), no other geographers are cited within this same discipline - which is surprising, given the fact that both geography and environmental psychology herald 'place' as their core concept.

A hypothetical explanation might relate to the fact that, despite in principle many scholars agree on cross-disciplinary fertilization, the actual moves in this direction are not so common or extensively performed. This results in academic disciplines which, in general, tend to remain rather self-confined - a point already noted a quarter of a century ago, exactly in relation to geography and psychology (Gold and Goodey 1983 - see also Kithcin et al. 1997). ${ }^{1}$

Alternatively, one can also consider the extent to which, after the works of Tuan and Relph, geographers have offered new contributions to the topic. Certainly, geographers have further investigated the notion of place in relation to political processes (Agnew 1987; Johnston 1991), its transformation in the age of globalization (Harvey 1989; Sack 1997), its cosmopolitan (Tuan 1996; Entrikin 1999) or progressive (Massey 1991)

character, its activation in forms of identity politics (Keith and Pile 1993), inclusion/exclusion (Creswell 1996), or local resistance (Escobar 2001; Castree 2004). 
These studies have contributed substantially to our knowledge of place, moving beyond the phenomenological focus on individual experience so to incorporate structures of political and economic powers (Rose 1995; Adams et al. 2001). Yet, in the process of focusing on new forms of social identity, which were previously under-investigated or under-theorized (e.g., gender, sex, class, race, ethnic minorities, disables, etc.), the personal, intimate relation between place and Self seems to have lost ground, being subsumed within an all-encompassing social(izing) discourse. It is not surprising, for instance, that as May (1996, p. 194) has noted and as recently Carter et al. (2007, p. 762) have recalled, relatively few empirical studies on the relationship between place and identity have so far been carried out.

The present article builds on an empirical study on meanings of place as discussed by ordinary people in individual interviews and focus groups. The discussions addressed the notion of place at four scales (local, regional, national and European). The article aims to revitalize the interest of geographers around the ways in which meanings of place intervene in the construction of the Self, both at a personal and a social level. The article draws on both geographical and psychological literatures, which are discussed in the next section. A theoretical scheme which links meanings of place and identity is then put forward. This scheme, incorporating insights from both humanist geography and social/environmental psychology, originates from the critical analysis of narratives of place and the Self gathered among the respondents of the present study. Final remarks follow.

\section{Place and identity in geography and psychology}

The study of the interconnections between natural environment and human culture has traditionally been at the centre of the geographical investigation. Yet, it was particularly in the early $20^{\text {th }}$ century, thanks mainly to the works of Vidal de la Blache and the French géographie 
humaine, that a more systematic exploration of the organic interaction between people and place was inaugurated (Buttimer 1971; Berdoulay 1981). French geographers contributed substantially to the study of how local communities transform and are transformed by the natural environment, giving way to geographically specific forms of social life or genres de vie. A few years later, a similar research focus was also adopted in the United States, under the guidance of Carl Sauer and his colleagues and students at Berkeley (Livingstone 1992). Their investigation of 'culture areas', i.e. socio-spatial ensembles which show specific identity traits, attracted the interest of various Anglo-Saxon geographers and became one of the dominant paradigms in Anglophone human geography at least until the mid-1960s (Hugill and Foote 1994).

Without entering into the details of this production, what matters here is to note the emphasis of these early studies on the 'social' or the 'cultural', conceived as something existing on itself, beyond the lives of the individuals (Duncan 1980). Individual existence and perceptions were not considered; they were simply absorbed within what later Zelinski (1973) would call the ‘superorganic entity’.

First anticipated in the works of Wright (1947), Lynch (1960), and Lowenthal (1961), the attention to the individual became more apparent with the rise of behavioral geography (Gold 1980; Cox and Golledge 1981). This sub-discipline focused on the psychological dimension of human action and as such it largely shared both research interests and techniques with environmental psychology (Spencer and Blades 1986; Kitchin et al. 1997). Individual perceptions, attitudes, and values were accurately measured and analyzed in statistical terms in order to explain human behavior in different contexts (e.g., spatial decision-making, environmental risk, and cognitive mapping). Despite the focus on place (or better, space) and the individual, issues of identity formation were largely absent from these studies. This concern emerged only in the 1970s, within the works of humanistic geographers. Highly critical of the positivist, scientist, and “dehumanizing” character (Kitchin et al. 1997, p. 558) of behavioral geography, humanistic geographers brought the existential dimension of an em-placed subject to the fore (Ley and Samuels 1978). Their goal was not to explain human behavior in space, but to map meanings of place from the perspective of unique individuals. Humanistic geographers rejected the notion of place as a measurable geometric space and privileged instead a notion of place as a field of care, a locus of emotional attachment, where the subject experiences events meaningful to her/his life (Relph 1976, p. 38, 42). 
The fact that humanistic geography largely drew on phenomenology and existentialism (Entrikin 1976) brought about an emphasis on human experience and on what Heidegger (1962) had called Dasein, the human subject's mode of being, which is always 'being-in-the-world', 'being in place'. This situatedness of the subject, in turn, explains the primacy of place in one's life, as the very existence of the Self is possible only in relation to a place (Casey 1996; Malpas 1999). To use an oft-cited phrase from Noël Arnaud (1950) quoted in Bachelard (1969, p. 137): je suis l'espace où je suis (I am the space where I am). The notion of place as a source of both individual attachment and identity was conceptually articulated by humanistic geographers under different terms: sense of place, topophilia, insideness, and rootedness. Although a distinction might be drawn among these notions with regard to the degree of the individual's self-consciousness (Tuan 1980b), it suffices here to say that all these terms testify of the efforts of humanistic geographers to describe the unique relation between Self and place.

In the early 1980s, this intellectual endeavor came under criticism mainly for its blindness towards the materiality of social life (Gregory 1981). The new ‘critical humanist geography' which emerged out of this critique and, more generally, as part of the 'cultural turn' in geography, has since opened to new theoretical contributions - cultural materialism, feminism, post-structuralism, post-modernism, and post-colonial theory (Pile 1993; Adams et al. 2001). Feminist authors, in particular, have criticized the 'undifferentiated' subject of humanistic geography and have striven to articulate this subject in terms of her/his gender, class, age, race, or ethnicity (Rose 1992). Yet, I would argue, in this transformation of the original humanistic project, the emphasis on the personal, existential dimension of the subject has faded away, somewhat obliterated by a new emphasis on social identity categories and structures of power. Social relations of domination, imbricated in forms of material production and social reproduction, have acquired a central position, subsuming or casting aside the intimate, unique, personal link between a subject and 'her/his' place. Accordingly, major attention has been paid to a place conceptualized and analyzed as a terrain of contestation, oppression, resistance, empowerment, or collective identification, resonating with various forms of identity politics (Keith and Pile 1993; Creswell 1996). Within this perspective, the subject ceases to matter as a unique individual and becomes a member of a collectivity, defined in terms of class, age, gender, ethnicity, race, or sexuality. 


\section{Environmental psychology}

While geographers - also those who have mapped the subject at the intersection between structure and agency (Thrift and Pile 1995) - seem to have increasingly turned to the social side of subjectivity, the focus on the intimate, existential relation between individuals and places has instead remained at the centre of environmental psychology. Building on the intuitions of humanistic geographers, with whom a short collaboration was indeed inaugurated in the early 1970s (Kitchin et al. 1997, p. 558), environmental psychologists have further explored notions of place identity, place attachment, place dependence, and sense of place. Emphasis on human behavior and positivistic hypothesis testing, though, have in time drawn environmental psychologists closer to behavioral geographers (Spencer and Blades 1986; Kitchin et al. 1997) than to humanistic geographers, whose research method, originally, was explicitly non-empirical (Entrikin 1976). Today, environmental psychologists still adopt an empirically grounded hypothesis-testing approach and some of them continue to be interested in human behavior; yet, their studies on the relationship between people and place might offer theoretical insights which can certainly interest geographers.

As mentioned above, major topics of investigation have been: place identity, place attachment, place dependence, and sense of place. To be true, there is no general agreement among psychologists about the definition of each of these concepts. Attachment is at times treated as a synonym of identity (Brown and Werner 1985; Stedman 2002, p. 563), correlated with it (Williams 2002; Hernandez et al. 2007, p. 311) or subsumed within it (Lalli 1992; Puddifoot 1995), occasionally in form of a prerequisite (Proshansky et al. 1983, p. 60-61; Twigger-Ross and Uzzell 1996, p. 206). In other cases, both identity and attachment are instead conceptualized as components of a superordinate category, sense of place (Hay 1998, p. 7; Jorgensen and Stedman 2001, p. 233). In other cases again, it is instead place attachment which is described to play the role of a superordinate category (Altman and Low 1992; Kyle et al. 2004; Brown and Raymond 2007). Despite this confusion about what term defines what and how these concepts are linked among themselves - something which has been widely lamented by environmental psychologists 
themselves (Giuliani and Feldman 1993, p. 273; Manzo 2003, p. 47; Chow and Healey 2008, p. 363; Lewicka 2008, p. 212) - it is undeniable that the numerous empirical investigations conducted within environmental psychology offer an important contribution towards an understanding of the ways in which people interact with places.

In an attempt to overcome the terminological confusion, I will offer here a brief sketch of the commonly agreed points, in environmental psychology, about the concepts of place mentioned above. Place identity is a term introduced in psychology in the early 1980s by Proshansky and colleagues and is defined as "a sub-structure of the self-identity of the person consisting of, broadly conceived, cognitions about the physical world in which the individual lives” (Proshansky et al. 1983, p. 59). In other words, it defines the personal identity of an individual in relation not to significant others, but to objects and things and the spaces and places in which they are found (Proshansky et al. 1983, p. 57). The 'environmental past' of an individual plays a key role in the formation of place identity. By this, Proshansky and colleagues (1983, p. 59) refer to spaces, places and their properties which have being meaningful in the life of an individual - something which Rowles (1983) calls 'autobiographical insideness'. Contrary to Tuan, Relph and Buttimer, Proshansky and colleagues - who nevertheless drew inspiration from the works of humanistic geographers - believe that place identity is the product of experiences, feelings, attitudes, and values, which are not only unconscious, but also conscious.

Place attachment is a term that environmental psychologists have increasingly used since the late 1970s (Giuliani and Feldman 1993, p. 268). Even in this case, the influence of humanistic geography, in particular Tuan's and Relph's notion of 'rootedness', is both expressly and widely acknowledged. A great majority of environmental psychologists agree that place attachment mainly stands for an emotional, affective bond between people and place (Giuliani and Feldman 1993, p. 271; Gustafson 2001b, p. 668); yet, a few psychologists also add a cognitive and a behavioral component to it (Low and Altman 1992, p. 5; Chow and Healey 2008, p. 363). Place attachment is generally associated with feelings of 'being at home', belonging, comfort, and security and some psychologists, echoing both Relph (1976, p. 31-33, 37) and Tuan (1980b, p. 264), affirm that it is a function of length of residence, which in turn helps developing a sense of familiarity with place (Hay 1998). Some of them also 
share both Tuan's and Relph's view on the unreflective character of this concept (Twigger-Ross and Uzzell 1996, p. 210) and regard it as a process rather than as a stable, fixed condition (Rubinstein and Parmelee 1992, p. 143).

As first theorized by Stokols and Schumaker (1981), the notion of place dependence refers to the utilitarian value that a place has in relation to other places in terms of satisfying an individual's specific goals and desired activities, which can range from sociability to services and aesthetic enjoyment (Stedman 2002). In this sense, place dependence is mainly a cognitive, rather than an affective concept. Other authors refer to a similar utilitarian value of place using different terms: place satisfaction (Stedman 2002), place evaluation (Guest and Lee 1983) and selfefficacy (Twigger-Ross and Uzzell 1996). The ongoing debate is whether place dependence is positively correlated with place attachment (Stedman 2002, p. 564; Kyle et al. 2004, p. 215), thus justifying the use of the concept of 'functional attachment' (Williams and Vaske 2003, p. 831) or, as others suggest (Guest and Lee 1983), satisfaction is neither necessary nor sufficient a condition for attachment.

Finally, the notion of sense of place has been widely deployed in environmental psychology. Even in this case, the direct reference is to Tuan's and Relph's works (Lalli 1992). Among the various notions of place discussed so far, sense of place is the most elusive, ill defined and controversial (Shamai 1991, p. 347; Williams and Stewart 1998, p. 18). This is not surprising, as also within humanistic geography, the concept was at times used as synonym of attachment, belonging, and identity, despite Tuan's attempt to set the terms of the discussion (Tuan 1980b). A minimal definition would refer to sense of place as the meanings attached to a spatial setting by an individual or a group (Jorgensen and Stedman 2001, p. 233). Yet, there seems to be an increasing acceptance among environmental psychologists to define sense of place as encompassing the cognitive (place identity), affective (place attachment), and conative (place dependence) components of people's attitude towards place (Jorgensen and Stedman 2001). In this sense, it seems both inaccurate and reductive to talk of place attachment as the environmental psychologist's equivalent of the geographer's sense of place (Brown and Raymond 2007, p. 90).

From a geographical perspective, one of the limits of environmental psychology is its focus on a relatively small scale (e.g. house, neighborhood, work place, leisure resorts, etc.) (Lalli 1992), leaving out a whole range of places at smaller scales where similar attitudes can 
also be at play and studied (see, for instance, Cuba and Hummon 1993; Bonaiuto et al. 1996; Devine-Wright and Lyons 1997). Connected with this critique is the absence, in most of environmental psychology studies, of an attention to the socio-economic processes which contribute to the construction of the relationship between people and places. Environmental psychology has been indeed criticized by social psychologists for being “individualistic, mentalistic, uncontested and apolitical” (Dixon and Durrheim 2000, p. 31). It has been said to rely on an ontological rather than a discursive notion of place (Dixon and Durrheim 2000; Manzo 2003), which inevitably prevents dealing with social and collectives processes and issues of power relations (Hopkins and Dixon 2006). This explains why, apart from a few attempts to bridge the two (Bonaiuto et al. 1996; Twigger-Ross and Uzzell 1996; Devine-Wright and Lyons 1997; Dixon and Durrheim 2000), there has been little exchange between environmental psychology and social psychology, as well as between environmental psychology and human geography, particularly since the 'cultural turn' has meant the privileging of the social over the individual dimension (Ley 2000, p. 44).

In the following section I will discuss a theoretical framework, based on the empirical analysis of meanings of place among ordinary people and local elites in four European case studies, which aims to capture the ways in which people's narration of place in personal and social terms resonate with two different moments, personal and social, in the life of an individual.

\section{Place and identity: a theoretical framework}

The empirical materials used in this section come from an extensive field work, carried out during May 2005 and January 2006 in four European regions: Lombardia (Italy); Pirkanmaa (Finland); North East of England (United Kingdom); and Languedoc-Roussillon (France). This fieldwork was aimed at providing empirical material for studying the relationship between territory and identity in the age of globalization. Territory was conceptualized at four scales: local, regional, national, and European. For the purpose of this research, I use the term territory as a 
synonym of place - a use which silently informs many geographical works in the Anglo-Saxon literature - and, following a mainstream interpretation, I refer to place in terms of a portion of geographic space filled with social relations, meanings and identities (Duncan 2000).

The research design was based on a mixed-method approach. This explains why the four regional case studies were chosen on the basis of a preliminary statistical analysis on survey data for territorial attachment. ${ }^{2}$ Although I cannot claim that these four regions are 'representative' of Western Europe as a whole, they capture a great variety of its different socio-economic conditions. In fact, Lombardia is one of the richest regions in Europe and a major 'engine’ of the European economy, followed by Pirkanmaa, whose regional capital, Tampere, has long been on the forefront of the knowledge economy and information society (Castells and Himanen 2002). Down the ladder, the North-East of England is a region still heavily affected by the closure of the coal mining sector, with a relatively high level of unemployment, high numbers of people living on benefits and low level of education (Colls and Lancaster 1992). Similarly, Languedoc-Roussillon is one of the poorest regions of France, with an economy essentially based on services for the domestic market and therefore rather impermeable to the effects of global economic competition (Giband 2005).

In each of these four regions, I conducted four focus groups, with 4-5 participants in each, males and females, aged 18-26 years old. I also administered about 100 semi-structured individual interviews with 'local elites' - here defined as any person with a political, institutional or social role within the local society. Data were transcribed and coded following an inductive approach, i.e. codes were not generated on the basis of an a priori theory, but on the observation of recurring patterns (Lofland and Lofland 1995; Weinberg 2002; Silverman 2004).

Although this research has generated a conspicuous amount of both quantitative and qualitative data, in this article I will focus only on qualitative information collected around the different meanings which both focus group participants and individual interviewees spontaneously referred to their town/village, region, nation and Europe.

On the basis of these meanings, I shall propose a theoretical framework which aims to capture the ways in which place intervenes in the construction of the Self. This theoretical scheme can be rendered visually in the form represented in Figure 1. 


\section{FIGURE 1 APPROXIMATELY HERE}

Rather than presenting this theoretical framework at the end of the discussion of the empirical materials, I have preferred to introduce it at the beginning, so to have enough space to explain its functioning. This move, however, should not confuse the reader. The above scheme, in fact, is not a model to be tested, but a diagrammatic representation of the proposed theoretical framework, which relies on the analysis of the empirical evidence collected.

My close examination of the referents used by the respondents to signify their places has led me to group them into two major categories: personal and social.

Personal referents revolve around the individual's unique web of personal relations (e.g. family, friends, and partners), his/her memories of past life (e.g. childhood and school time), relevant past experiences (e.g. first love encounters), and present ordinary practices (e.g., working and shopping). In this sense, echoing a phenomenological perspective, place can be conceptualized as "a cumulative archive of personal spatial experience” (Paasi 2001, p. 25).

Social referents refer instead to material and/or symbolic characteristics which exist independently from the subject who experiences them, which cannot be reduced to the history of an individual (Paasi 1991, p. 249), and which shape the specific 'identity' of a given geographic space: history, traditions, culture, language, institutions, (character of) people, landscape features, economic activities, etc.

This distinction between personal and social is not very dissimilar from the one proposed, in environmental psychology, by Gustafsson (2001a). Even in this empirical study, referents of place are organized around personal ('Self') and social ('Others') categories; yet, given the emphasis of environmental psychology on the natural features of place, Gustafsson creates an autonomous category ('Environment') for landscape-related referents, rather than considering them as part of the 'social' features of place. 
Both personal and social referents can lead to the discursive construction of place as 'home' (Blunt, 2005, p. 506). I use here this term in the sense put forward by the phenomenological literature. According to Relph (1976, 40), for instance, home reflects "an attachment to a particular setting, a particular environment, in comparison with which all other associations with places have only a limited significance”. Home is a notion which, in the past, has been at the center of a fierce feminist critique, which has rejected it as a space filled with gendered and patriarchal relations of oppression, violence and fear (Varley, 2008). Recently, feminist geographers have partly rescued the notion of home, stressing its ambiguous character (Blunt and Dowling, 2006). By relying on a phenomenological understanding of home I do not mean to escape issues of power relations which inform this space, but to keep analytically separate two different notions: home as a material domestic(ated) space, which can be associated with both security and violence; and home as a symbolic space, which resonates instead with feelings of attachment and familiarity. It is this latter notion that the article privileges, as it was the notion mostly evoked by the respondents when they talked of place as 'home'.

Personal referents (family, friends, childhood memories, etc.) were those used most often by the respondents to define this notion of place as home - a point also supported by the literature (Cuba and Hummon 1993, p. 117, 126; Manzo 2005). As an Italian male participant, for instance, affirmed: "I always like it when I go back [...] but I don't have a [clear] awareness of the place where I was born. I am not aware, I don't know habits and customs [of the place] or... I mean, it is just sentimental, because it is nice to go back where I grew up as a child".

In this quote, the respondent is clearly aware of the distinction between personal and social referents of place and declares to feel a sense of attachment only through his own unique, personal connection to place. Yet, in other accounts, it was the reference to some form of social dimension which respondents highlighted as a discursive resource in the construction of place as home. Consider, for instance, the following quote from an English female participant: 
“I've got quite a lot of heritage there, so yes, that's my version of the North East and I think there's a certain quality of person in this area with a certain understanding which always feel quite comfortable and it's like the homecoming, you know when you're back in the North, when you get on the train from wherever, I feel anyway, I know when I'm coming back home.”

In this case, it is the existence of a certain social dimension ("a certain quality of persons") which mainly contributes to the rendition of the North East as 'home'. Moreover, the fact that this 'home' is not the local village/town, but the region suggests that any space at any scale can indeed be 'home' (Jackson 1995). Not surprisingly, some respondents felt that, in certain circumstances, also Europe can be ‘home’:

Interviewer: What does Europe mean for you? Or you don't have any European identity?

Finnish interviewee (male): Um... when I am in Finland, Europe I must say means nothing. But when I am in the USA or Japan, that it means, because coming from Japan to Frankfurt for instance you feel home.

Interviewer: Just because of the passport or the things look more familiar?

Yes, it is easy to read the signs, and what is going on...

In other cases again, it was instead a clear mixture of personal and social referents which were deployed by the respondents to construct their place as home, as exemplified by the following account of a French female interviewee:

Interviewer: What does it mean for you, the place where you live?

Interviewee: The intimate sphere, sensitivity... [it's] my small sector, my canton, my village...it's my village, since I have lived there, since it is a rural village, since the roots of my family are there, since the landscape is familiar to me, etc. the heritage and everything. 
A sense of intimacy, which clearly indicates an attachment to a place felt as 'home' and which also defines the interviewee's identity of place, can therefore emerge through personal referents, social referents or both. Some respondents also showed a sentiment of place attachment dictated by a sort of place dependence, as, for instance, illustrated by the following quote from an English female interviewee:

"I live in one of the villages. My mother lives in the city [Durham]. When I was 12 we moved into the city, but at the moment I live in Sherburn which is 3 miles out, so I think I have the best of both worlds, because it's a beautiful city, it takes me 10 minutes to drive into the city, but at the same time I can walk my dog in the countryside... and the village community is very nice... I am lucky: my parents came to such a nice place to call home really..."

The possibility that the 'quality of life' offered by a place might generate a sense of attachment confirms past findings in environmental psychology (Williams and Vaske, 2003). The effect of place dependence on people emerged particularly in the case of Tampere, Pirkanmaa's capital, one of Finland's preferred cities for its good quality of life. As put by one female participant, not originally from Tampere: “There's a kind of atmosphere here something that I'm not actually even able to explain, which has always made me feel really at home and nice here in Tampere... That's probably why I have basically found my way here.” As further explained by one Finnish female interviewee, referring to the attitudes of many students who moved to Tampere: "Well, when they find a place in which they feel comfortable they feel like [it is] the place where they want to be...I met a lot of young students who felt saying "I come from Tampere" even if they had move here just for a couple of months...it is very fast, the process of belonging."

The rendition of place as home closely resembles the 'field of care' of humanist geographers (Tuan 1974a, p. 241; Relph 1976, p. 38). The home place becomes a profound center of human existence, an “irreplaceable center of significance” in the life of an individual (Relph 1976, p. 
39). This is a point which also feminist geographers have stressed. According, for instance, to Blunt and Varley (2004), the notion of home invokes as sense of place which is intimately tied to a sense of self (Blunt and Varley, 2004). As exemplified by one Finnish female interviewee: "There are different kind[s] of things that have happened in my life which have happened here. So I think for me no other place in Finland or in the world could ever get that place in my life". This intense, unique, personal link between an individual and place - a sense of 'autobiographical insideness' - brings to the fore the question of personal identity. This concept does not merely echo the notion of place identity put forward by Proshansky and colleagues (1983, p. 59), but it connects more widely with the phenomenological reflection on human existence as ineluctably em-placed (Casey, 1996). Building on the insights of both environmental psychology and humanistic geography, it is possible to discern in the discursive rendition of place as home a sort of longing for a place which is home to oneSelf, in which one can 'find' her/him-Self. Among others, psychologists have widely debated whether the Self should be conceptualized as a singular and relatively stable something or as an ongoing process, a verb ('selfing') rather than a noun (self) (McAdams 1997). Different intellectual paradigms have privileged different views. ${ }^{3}$

It is not my goal here to enter the debate about the nature of the Self - discussing whether this is an ontological entity, a discursive occurrence, or a product of both innate characteristics and social interaction (Hammersley and Treseder 2007; Smith and Sparkes 2008). My focus is rather on the fact that respondents talked of themselves as being or feeling at home in certain places. This suggests the relevance of place in the activation of what can be called 'personal identity', i.e., a form of self-understanding aimed at answering to 'me' the existential question 'who I am' (Benson 2001, p. 89). The use of the term 'identity' here does not imply any essentialist or reifying logic, rather a process through which the individual turns to her/him-Self, both cognitively and emotionally. Personal identity recalls some aspects of Giddens's (1991, p. 3235, 53) notion of 'self-identity’, i.e., a reflexive project based on a person's biography, as well as some features of Brubaker and Cooper’s (2000, p. 17-18) notion of 'self-understanding', i.e., one's own understanding of who one is.

To be sure, personal identity does not occur in isolation, but in relation to specific material and socio-geographical contexts. As such, personal identity is certainly shaped by the social and cultural situatedness of the individual, as largely maintained today by human geographers. 
In this sense, one can agree with Jenkins (2004, p. 4) that “all human identities are by definition social identities”. Yet, following Lipman (2006: 622), I maintain that, however socially responsive or even socially created the Self might be, an individual, private dimension remains. Moreover, I would argue that it is not that all identities are 'social' in the sense that they are to be expressed socially, i.e., as social labels in discourses and practices of social inclusion/exclusion. When place is evoked as a personal, intimate home for oneSelf, it does not tend to be filled with meanings of (social) inclusion/exclusion, but it remains open to the fruition, attachment, and belonging of any other individual.

At the same time, though, place can indeed be discursively activated as a socio-spatial category. In this case, a clear identity of place emerges (although always possible of contestation and resistance), which implicates and is implicated in discourses and practices of social inclusion/exclusion. Most respondents indeed referred to their places in terms of some identifying features, which, in turn, transform place into an identity marker itself, triggering discourses of self-identification and social categorization. In social psychology, self-identification refers to an individual who claims to belong to a certain group, whereas social categorization is the way others look at the individual, not as a unique human being, but as a member of a group (Chryssochoou 2003; Triandafyllidou and Wodak 2003). The two following quotes - the first from a Finnish male interviewee and the second from a focus group discussion among young English participants (names are fictitious) - can be used to exemplify, respectively, these two aspects of social identity:

"I have been born here, I speak a [the] Finnish language, I have been at school here, it is all my personality Finnish."

Interviewer: People where? What kind of people misrepresent...

Leslie: People from the South

Interviewer: What kind of idea do they have, people in the South?

Leslie: Just that we're, idiots

Samantha: Loudmouthed

Interviewer: Loudmouthed, idiots... 
Robert: Yes, commoners

Interviewer: Oh, commoners

Samantha: I think they think all the boys are violent and all the girls are whores

Leslie: Yes and that they're better than us [people agree] so I'm quite attached to the North East

Both self-identification and social categorization are more or less explicitly associated with discourses of inclusion/exclusion (Eisenstadt and Giesen 1995, p. 74; Chryssochoou 2003, p. 235-6). In the first account above, Finland is the place where people speak Finnish and those who do not might be considered 'out of place' (Creswell 1996). Similarly, in the second account, focus groups participants are socially categorized in a derogatory way by people from the South of England. This discourse clearly reinforces social identity boundaries and, as a consequence, leads to the strengthening of a sense of pride for one’s own group, confirming the insights of social identity theory (Tajfel, 1982).

The distinction between place as 'home for the Self' and as a socio-spatial category is not completely new, as it was somewhat already present in humanistic geography. Relph (1976, p. 36, 142), for instance, affirmed that the same place can be felt both in term of a 'personal place', uniquely and privately experienced by an individual, and as a cultural, communal, and symbolic place. By echoing studies in environmental psychology, also the sociologists Cuba and Hummon (1993, p. 112-113) have put forward a similar distinction, by talking of 'place as affiliation' (associated with a sense of being at home, being comfortable, familiar and 'really me') and 'place as display' (used to communicate certain features of an individual to others).

This distinction, however, should not lead one to think of place in ontological terms, as if place comes with two distinct qualities. Place as a 'home for the Self' or place as a social identity marker do not refer to qualities of place, but they simply reflect two possible ways in which an individual can relate to place. Moreover, as an attentive reader might have already noted from some of the above quotes, these two dimensions at times may not be so different, as one can imply the other. Consider, for instance, the ways in which a couple of Finnish interviewees, a woman and a man respectively, talked of their sense of place attachment in relation to language: 
Pori my hometown, maybe... when I see people from Pori and I hear people talk...

Interviewer: The dialect?

Yes, [it feels] good for me and always when I see people from Pori we have some kind of connection, even if I don't know these people. I don't know why, because I left Pori when I was so young.

Is that I feel at home when I hear the language spoken [...]. My name is foreign and I was growing up, my name... could not be pronounced... but when I speak the ice melts immediately.

In both cases, language is a social referent which generates feelings of home. Yet, this home it is not just the home of a unique individual, but of a member of a group, who shares with other members a common home-land. This tendency of 'home' to become 'home-land' (and potentially the other way round) seems to be implicitly present in the use of social referents qua social, whereas it seems less likely when personal referents are used. In fact, only in few instances respondents showed to mobilize personal referents to construct place as a socio-spatial category, as, for instance, exemplified in the following account of another Finnish interviewee:

I feel that my parents and grand parents they lived here and they worked for this country - now I feel that I have to do something... and work here and try to make it a better place here.

In this case, the history of the nation is the biographical history of an individual and her familial ties - the genealogy of the nation blends with the genealogy of the individual and the 'home-land' is not different from one's 'home'. 
Finally, I should point out that my theoretical understanding of personal identity and social identity does not fall into the ontological trap identified and criticized by social psychology (Chryssochoou 2003). From this perspective, to distinguish between personal and social identities risks to reify both of them as two separate ontological entities, crystallizing them as essential qualities which people 'have' or 'are' (Triandafyllidou and Wodak 2003, p. 211). While I largely share this critique, I should reiterate that, in my theoretical framework, personal identity and social identity do not refer to some essential qualities attached to an individual, but to different moments in the life of an individual - a moment of self-understanding directed towards oneSelf and a moment of self-identification and social categorization discursively activated in social contexts. This does not imply the existence of a private or a public Self (McAdams 1997, p. 62, 69), but indeed two different moments, private and public, in the life of the Self, however unitary or fragmented this might be. Moreover, I should point out that there is not a fixed closure between these two moments, as the personal, unique entanglement between an individual and a place can certainly be informed by logics, discourses, and practices of place conceptualized as a socio-spatial category and the other way round. In fact, as the three last quotes suggest, home and home-land might at times be imbricated into a mutually constitutive relation. Similarly, the personal and private encounter of the Self with a place (personal identity) might be affected by and affect social discourses and practices of self-identification and social categorization (social identity). This, however, does not infringe the theoretical and analytical value of conceiving the relationship between place and Self as constituted by two distinct, even though permeable dimensions.

\section{Conclusion}

Since the 1980s, with the emergence of the 'cultural turn', the attention to the individual, a central dimension in humanistic geography, has given way to a new focus on the social. Geographers have privileged analytical accounts of people-place relations which emphasize the role of 
social contexts, power dynamics, cultural materiality, etc. Today, it is largely agreed that the way an individual relates to place cannot be understood but in the light of her/his socio-economic situatedness. This perspective has certainly enriched the early contributions of humanistic geography, which largely avoided dealing with the materiality of social life (Gregory 1981) and the socio-biographical aspects of the Self (Rose 1992). Yet, in this shift from the individual to the social it seems that something has been lost - the personal, intimate, existential relation between the individual and her/his place. On the one hand, it is undeniable that the way an individual relates to place is informed by her/his socio-economic situatedness. Yet, on the other hand, it is also undeniable that not any moment in the life of an individual should be a social moment, i.e., discursively articulated or performed in a social context. Many geographers have somewhat lost interest for this phenomenological dimension which, notwithstanding a social constructivist paradigm, still reflects some of the ways in which individuals construct meanings of place.

Borrowing from the early works of humanistic geographers, environmental psychology has shown an unaltered interest for this personal, intimate link between place and individual. Its empirical works have contributed to the grounding of various theoretical notions imbricated with place (e.g., place identity, place attachment, place dependence, and sense of place), even though some conceptual overlapping and disagreement still remain.

In the present article, I have drawn on the insights of both humanistic geography and environmental psychology in order to build a theoretical framework aimed at linking meanings of place and aspects of the Self. By relying on narratives of place at different scales, collected in individual interviews and focus groups in four different European regions, I have shown that, however discursively constructed and filled with social referents a place might be, it can still be felt as a locus of intimacy, emotionally private, where discourses (and practices) of social inclusion/exclusion are largely absent. I have also suggested, though, that this place as 'home for the Self' can at times transform into a 'homeland', a social identity marker, associated with discourses and practices of social inclusion/exclusion. 
Implicit in this account is an invitation to reconsider the importance of the personal, existential dimension in informing the 'topographies of everyday life', ${ }^{4}$ rather than downplaying this dimension either as psychologically 'mentalistic' (Dixon and Durrheim 2000, p. 31) or as geographically 'trivial' (Pile 1993, p. 128). Not everything that matters, with regards to the relationship between people and place, should be seen as a product of social discourses (Antaki and Widdicombe 1998) or should be understood in terms of human agency and socio-material contexts of action (Gregory 1981). In the first case, the risk is to fall into a form of essentializing social constructionism, where, in the words of Conradson (2005, p. 105), the individual "becomes merely an effect of external discourses and practices”. In the second case, the risk is to miss relevant personal aspects of the relationship between Self and place. Alternative strategies of inquiry have been put forward in geography, among which it is worth mentioning those aimed at investigating the psychoanalytic (Thrift and Pile 1995) and emotional (Davidson et al. 2005) dimensions of the Self. Although the length of this article does not allow for a full treatment of their arguments, it suffices here to say that these approaches have substantially contributed to keep alive an interest in the personal, intimate, existential moments of the Self-place relation. The present article has similarly stressed the relevance of these 'personal moments of place' and suggested how, along with socially articulated discourses of place, they implicate and are implicated in the ways the individual expresses her/him-Self. 
Figure 1. Meanings of place and the process of personal and social identification.

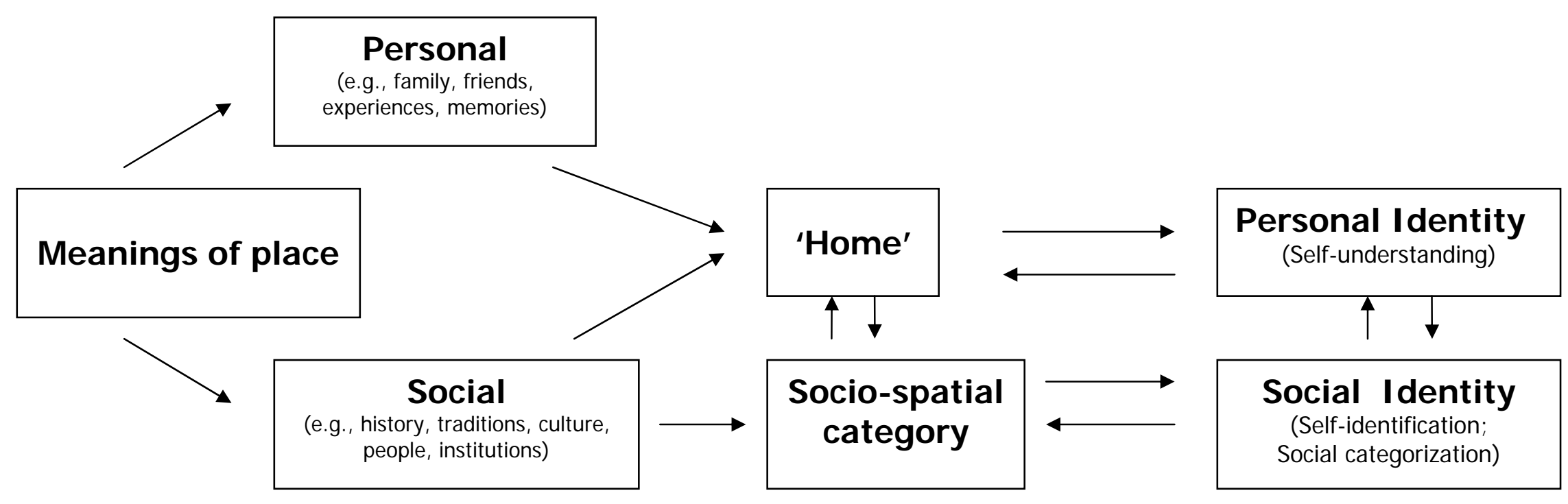




\section{Acknowledgments}

The field work of data collection was made possible thanks to a financial grant obtained from the National Science Foundation (USA): Doctoral Dissertation Research Improvement grant no. 0503405, conferred on 30 Dec, 2004. The author would also like to thank the anonymous reviewers for their helpful comments.

\section{References}

Adams, P.C., Hoelscher, S.D. \& Till, K.E. (2001). Place in context. Rethinking humanist geographies. In Adams, P.C., Hoelscher, S.D. \& Till, K.E. (eds.), Textures of place (pp. xiii-xxxiii). Minneapolis: University of Minnesota Press.

Agnew, J. (1987). Place and politics. Boston: Allen and Unwin.

Altman, I.andLow, S. M. (1992). Place attachment. New York: Plenum Press.

Antaki, C., \& Widdicombe, S. (Eds.) (1998). Identities in Talk. London: Sage.

Arnaud, N. (1950). L'État d'ébauche. Paris: Le Messager Boiteux.

Bachelard, G. (1969). The poetics of space. Boston: Beacon Press.

Benson, C. (2001). The cultural psychology of self. London: Routledge.

Berdoulay, V. (1981). La formation de l'école française de géographie. Paris: Bibliothèque Nationale.

Blunt, A. (2005). Cultural geography: cultural geographies of home. Progress in Human Geography 29, 505-515.

Blunt, A., \& Varley, A. (2004). Geographies of home. Cultural Geographies, 11, 3-6. 
Blunt, A., \& Dowling, R. M. (2006). Home. London: Routledge.

Bonaiuto, M., Breakwell, G.M., \& Cano, I. (1996). Identity processes and environmental threat. Journal of Community \& Applied Social Psychology, 6, 157-175.

Bondi, L., Davidson, J., \& Smith, M. (2005). Introduction: Geography's 'emotional' turn. In Davidson, J., Bondi, L., \& Smith, M. (Eds.) Emotional geographies, (pp. 1-18). Aldershot: Ashgate.

Brown, B., \& Werner, C. (1985). Social cohesiveness, territoriality, and holiday decorations. Environment and Behavior, 17, 539-565.

Brown, G., \& Raymond, C. (2007). The relationship between place attachment and landscape values. Applied Geography, $27,89-111$.

Brubaker, R., \& Cooper, F. (2000). Beyond 'identity'. Theory and Society, 29, 1-47.

Buttimer, A. (1971). Society and milieu in the French geographic tradition. Chicago: Rand McNally.

Buttimer, A., \& Seamon, D. (Eds.) (1980). The human experience of space and place. London: Croom Helm.

Carter, J., Dyer, P., \& Sharma, B. (2007). Dis-placed voices: sense of place and place-identity on the Sunshine Coast. Social and Cultural Geography, 8, 755-773.

Casey, E.S. (1996). How to get from space to place in a fairly short stretch of time. In Feld, S. \& Basso, K. (Eds.), Senses of Place (pp. 13-52). Santa Fe: School of American Research.

Castells, M., \& Himanen, P. (2002). The Information Society and the Welfare State. Oxford: Oxford University Press.

Castree, N. (2004). Differential geographies: place, indigenous rights and 'local' resources. Political Geography, 23, $133-167$.

Chow, K., \& Healey, M. (2008). Place attachment and place identity. Journal of Environmental Psychology, 28, 362-372.

Chryssochoou, X. (2003). Studying identity in social psychology. Journal of Language and Politics, 2, 225-241.

Colls, R., \& Lancaster, B. (Eds.) (1992). Geordies. Edinburgh: Edinburgh University Press. 
Conradson, D. (2005). Freedom, space and perspective: moving encounters with other ecologies. In Davidson, J., Bondi, L., \& Smith, M. (Eds.), Emotional geographies, (103-116). Aldershot: Ashgate.

Cox, K.R. \& Golledge, R.D. (Eds.) (1981). Behavioral problems in geography revisited. New York: Methuen.

Creswell, T. (1996). In place, out of place. Minneapolis: University of Minnesota Press.

Cuba, L., \& Hummon, D.M. (1993). A place to call home. The Sociological Quarterly, 34, 111-131.

Davidson, J., Bondi, L., \& Smith, M. (Eds.) (2005). Emotional geographies. Aldershot: Ashgate.

Devine-Wright, P. \& Lyons, E. (1997). Remembering pasts and representing places. Journal of Environmental Psychology, 17, 33-45.

Dixon, J. \& Durrheim, K. (2000). Displacing place-identity. British Journal of Social Psychology, 39, 27-44.

Dixon, J. \& Durrheim, K. (2004). Dislocating identity. Journal of Environmental Psychology, 24, 455-473.

Duncan, J. (1980). The Superorganic in American Cultural Geography. Annals of the Association of American Geographers, 70, 181-198.

Duncan, J. (2000). Place. In Johnston, R.J., Gregory, D., Pratt, G., \& Watts, M. (Eds.), The Dictionary of Human Geography (pp. 582-584). Oxford: Blackwell.

Eisenstadt, S.N., \& Giesen, B. (1995). The construction of collective identity. Archives Européennes de Sociologie, 36, 72-102.

Entrikin, N.J. (1999). Political Community, Identity and Cosmopolitan Place. International Sociology, 14, $269-282$.

Entrikin, N.J. (1976). Contemporary humanism in geography. Annals of the Association of American Geographers, 66, 615-632.

Escobar, A. (2001). Culture sits in places. Political Geography, 20, 139-174.

Giband, D. (2005). Languedoc-Roussillon. In Giblin, B. (Ed.), Nouvelle Géopolitique des Régions Francaises (pp.733-781). Paris: Fayard.

Giddens, A. (1991). Modernity and Self-Identity. Stanford: Stanford California Press.

Giuliani, M.V. \& Feldman, R. (1993). Place attachment in a developmental and cultural context. Journal of Environmental Psychology, 13, 267274. 
Gold, J.R. (1980). An introduction to behavioural geography. Oxford: Oxford University Press.

Gold, J.R. \& Goodey, B. (1983). Behavioural and perceptual geography. Progress in Geography, 7, 578-586.

Gregory, D. (1981). Human agency and human geography. Transactions of the Institute of British Geographers, 6, 1-18.

Guest, A.M. \& Lee, B.A. (1983). Sentiment and evaluation as ecological variables. Sociological Perspectives, 26, 159-184.

Gustafson, P. (2001a). Meanings of place. Journal of Environmental Psychology, 21, 5-16.

Gustafson, P. (2001b). Roots and routes. Environment and Behavior, 33, 667-686.

Hammersley, M. \& Treseder, P. (2007). Identity as an analytic problem. Qualitative Research, 7, 283-300.

Harvey, D. (1989). The Condition of Postmodernity. Oxford: Blackwell.

Hay, R. (1998). Sense of place in developmental context. Journal of Environmental Psychology, 18, 5-29.

Heidegger, M. (1962). Being and time. New York: Harper and Row.

Hernandez, B., Hidalgo, C.M., Salazar-Laplace, E.M., \& Hess, S. (2007). Place attachment and place identity in natives and non-natives. Journal of Environmental Psychology, 27, 310-319.

Hopkins, N., \& Dixon, J. (2006). Space, place, and identity. Political Psychology, 27, 173-185.

Hugill, P.J. \& Foote, K.E. (1994). Re-reading cultural geography. In Foote, K.E., Hugill, P.J., Mathewson, K., \& Smith, J.S. (Eds.) Re-reading cultural geography (pp.9-23). Austin: University of Texas Press.

Jackson, M. (1995). At Home in the World. Durham: Duke University Press.

Jenkins, R. (2004). Social Identity. London: Routledge.

Johnston, R.J. (1991). A question of place. Oxford: Blackwell.

Jorgensen, B.S. \& Stedman, R.C. (2001). Sense of place as an attitude. Journal of Environmental Psychology, 21, 233-248.

Keith, M., \& Pile, S. (Eds.) (1993). Place and the Politics of Identity. London: Routledge. 
King, G., Keohane, R.O., \& Verba, S. (1994). Designing Social Inquiry. Princeton, NJ: Princeton University Press.

Kitchin, R.M., Blades, M., \& Golledge, R.D. (1997). Relations between psychology and geography. Environment and Behavior, $29,554-573$.

Kyle, G., Graefe, A., Manning, R., \& Bacon, J. (2004). Effects of place attachment on users' perceptions of social and environmental conditions in a natural setting. Journal of Environmental Psychology, 24, 213-225.

Lalli, M. (1992). Urban-related identity. Journal of Environmental Psychology, 12, 285-303.

Lewicka, M. (2008). Place attachment, place identity, and place memory. Journal of Environmental Psychology, 28, $209-231$.

Ley, D. (2000). Behavioural geography. In Johnston, R.J., Gregory, D., Pratt, G., \& Watts, M. (Eds.), The Dictionary of Human Geography (pp. 42-45). Oxford: Blackwell.

Ley, D., \& Samuels, M.S. (Eds.) (1978). Humanistic geography. London: Croom Helm.

Livingstone, D.N. (1992). The Geographical Tradition. Oxford: Blackwell.

Lofland, J., \& Lofland, L.H. (1995). Analyzing Social Settings. Belmont, CA: Wadsworth.

Low, S.M., \& Altman, I. (1992). Place attachment. In Altman, I., \& Low, S. (Eds.), Place attachment (pp. 1-12). New York: Plenum Press.

Malpas, J.E. (1999). Place and Experience. Cambridge: Cambridge University Press.

Manzo, L.C. (2003). Beyond house and haven. Journal of Environmental Psychology, 23, 47-61.

Manzo, L.C. (2005). For better or worse: exploring multiple dimensions of place meaning. Journal of Environmental Psychology, 25, 67-86.

Markus, H. (1977). Self-schemata and processing information about the self. Journal of personality and social psychology, 35, 63-78.

Massey, D. (1991). A global sense of place. Marxism Today, 24-29.

May, J. (1996). Globalization and the politics of place. Transactions of the Institute of British Geographers, 21, 194-215.

Mcadams, D.P. (1997). The case for unity in the (post)modern self. In Ashmore, R.D., \& Jussim, L. (Eds.), Self and identity (pp. 46-78). Oxford: Oxford University Press. 
Muñoz González, B. (2005). Topophilia and topophobia: The home as an evocative place of contradictory emotions. Space and Culture 8, 193213.

Onorato, R.S. and Turner, J.C. (2004). Fluidity in the self-concept. European Journal of Social Psychology, 34, 257-278.

Paasi, A. (1991). Deconstructing regions: Notes on the scales of spatial life. Environment and Planning A, 23, 239-256.

Paasi, A. (2001). Europe as a social process and discourse - Considerations of place, boundaries and identity. European Urban and Regional Studies, 8, 7-28.

Pile, S. (1993). Human agency and human geography revisited. Transactions of the Institute of British Geographers, 18, $122-139$.

Proshansky, H.M., Fabian, A.K., \& Kaminoff, R. (1983). Place-identity: Physical world socialization of the self. Journal of Environmental Psychology, 3, 57-83.

Puddifoot, J.E. (1995). Dimensions of community identity. Journal of Community and Applied Psychology, 3, 357-370.

Relph, E. (1976). Place and Placelessness. London: Pion.

Rose, G. (1992). Feminism and geography. London: Polity Press.

Rose, G. (1995). Place and Identity. In Massey, D., \& Jess, P. (Eds.), A Place in the World (pp. 87-132). Oxford: Open University Press.

Rowles, G.D. (1983). Place and personal identity in old age. Journal of Environmental Psychology, 3, 299-313.

Rubinstein, R.L., \& Parmelee, P.A. (1992). Attachment to place and the representation of the life course by the elderly. In Altman, I., \& Low, S.

(Eds.), Place attachment (pp. 139-163). New York: Plenum Press.

Sack, R. (1997). Homo Geographicus. Baltimore: The Johns Hopkins University Press.

Sacks, H. (1992). Lectures on conversation Oxford: Blackwell.

Shamai, S. (1991). Sense of place: an empirical measurement. Geoforum, 22, 347-358.

Silverman, D. (2004). Qualitative Research. Thousand Oaks, CA: Sage Publications. 
Smith, B., \& Sparkes, A.C. (2008). Contrasting perspectives on narrating selves and identities. Qualitative Research, 8, 5-35.

Spencer, C., \& Blades, M. (1986). Pattern and process: a review essay on the relationship between behavioural geography and environmental psychology. Progress in Human Geography, 10, 230-248.

Stedman, R.C. (2002). Toward a social psychology of place. Environment and Behavior, 34, 561-581.

Stokols, D., \& Shumaker, S.A. (1981). People in places. In Harvey, J.H. (Ed.), Cognition, social behavior, and the environment (pp.441-488). Hillsdale, NJ: Lawrence Erlbaum Associates.

Tajfel, H. (Ed.) (1982). Social identity and intergroup relations. Cambridge: Cambridge University Press.

Thrift, N., \& Pile, S. (Eds.) (1995). Mapping the subject. London: Routledge.

Triandafyllidou, A., \& Wodak, R. (2003). Conceptual and methodological questions in the study of collective identity. Journal of Language and Politics, 2, 205-223.

Tuan, Y.-F. (1974a). Space and place. Progress in Geography, 6, 211-252.

Tuan, Y.-F. (1974b). Topophilia. New York: Columbia University Press.

Tuan, Y.-F. (1980a). Landscapes of fear. Oxford: Blackwell.

Tuan, Y.-F. (1980b). Rootedness versus sense of place. Landscape, 24, 3-8.

Tuan, Y.-F. (1996). Cosmos and Hearth. Minneapolis: University of Minnesota Press.

Turner, J.C., Hogg, M.A., Oakes, P.J., Reicher, S.D., \& Wetherell, M. (1999). Rediscovering the social group: A self-categorization theory. Blackwell.

Twigger-Ross, C.L. \& Uzzell, D.L. (1996). Place and identity process. Journal of Environmental Psychology, 16, 205-220.

Varley, A. (2008). A place like this? Stories of dementia, home, and the self. Environment and Planning D: Society and Space 26, 47-67

Weinberg, D. (2002). Qualitative Research Methods. Malden, Mass.: Blackwell. 
Williams, D.R. (2002). Leisure identities, globalization, and the politics of place. Journal of Leisure Research, 34, 351-367.

Williams, D.R., \& Stewart, S.I. (1998). Sense of place. Journal of Forestry, 96, 18-23.

Williams, D.R., \& Vaske, J.J. (2003). The measurement of place attachment. Forest Science, 49, 830-840.

Zelinski, W. (1973). The Cultural Geography of the United States. Englewood Cliffs, NJ: Prentice Hall.

\footnotetext{
${ }^{1}$ This is not surprising, as it is intrinsic in the notion of discipline itself, as Foucault might remind us.

${ }^{2}$ To focus on 'attachment' rather than 'identity' was a forced choice, as the series of Eurobarometer survey data (the only data set which offers extensive European coverage across the years) does not have a 'trend' question about place identity at multiple scales. Methodologically, Eurobarometer survey data for European attachment (Eb 60.1 2003) were cross-tabulated with Eurostat (2001-2003) data for regional GDP measured in terms of purchasing power parity. The choice of clustering regions in terms of their socio-demographic indicators (independent variables) was taken in order to avoid the selection bias that would result from sampling regions on the basis of territorial attachment, i.e. the dependent variable (King et al. 1994). Additional information on the method of the selection of the regional case-studies is available from the Author upon request.

${ }^{3}$ While self-schema theory (Markus 1977) have tended to conceive the Self as a relatively stable cognitive representation or schema, both social identity theory (Tajfel 1982) and self-categorization theory (Turner et al. 1999) have privileged the importance of context (i.e., the social dimension) over (individual) schemas (Onorato and Turner 2004). More recently, with the so-called cultural, linguistic, discursive, or narrative turn, largely influenced, in psychology, by Sacks's (1992) studies on language, conversational analysis has instead advanced the notion of a fragmented Self, constantly in flux, plural, which occurs through inter-subjective talks, thus negating the existence of any pre-social, pre-discursive, and unitary Self (Antaki and Widdicombe 1998).

${ }^{4}$ The phrase is borrowed from Bondi et al. (Bondi et al. 2005, p.1).
} 